achievement - with help from friends and followers who cleaned up his prose and kept it updated through five editions. He never finished the grand survey that he dreamed of writing about the entire Pacific Coast, from Baja California to British Columbia. On 8 May 1948, a train hit Ricketts at a crossing near Cannery Row, as he was preparing for an expedition north to the outer shores with Steinbeck. He died three days later.

Ricketts' work was never published in scientific journals. His prescient analysis of the crash of the California sardine fishery was published in a local paper. His best ideas about ecology and humanity found voice in the writings of his friends, Steinbeck and Campbell. Now the whole life and work of Ed Ricketts can be found between the covers of Beyond the Outer Shores.

Jon Christensen is a Steinbeck fellow at San Jose State University, San Jose, California 95192-0090, USA.

\section{Peas and helices}

\section{Mendel's Legacy: The Origin of Classical Genetics \\ by Elof A. Carlson \\ Cold Spring Harbor Laboratory Press: 2004. 352 pp. $\$ 45$}

\section{Garland E. Allen}

Elof A. Carlson has added another important book to his list of publications on the history of genetics. Mendel's Legacy, in one sense a follow-up to Carlson's much earlier but still very useful The Gene: A Critical History (1966), represents the culmination of his work so far on the historical origins of classical genetics in the first half of the twentieth century.

Carlson defines classical genetics both chronologically and conceptually. He covers the first half of the twentieth century from the rediscovery of Mendel's work in 1900 to the publication of Watson and Crick's paper on the structure of DNA in 1953, and encompasses a number of strands of scientific thought going back into the nineteenth century. He justifies ending his story with the discovery of the double helix on the grounds that none of the preceding work based on the mendelian and chromosome theories led directly to discoveries about the molecular basis of heredity. Nor has classical genetics been replaced, in Carlson's view, by molecular genetics. Rather, the two have been integrated such that, although the molecular details of genetics are quite different from anything classical geneticists could have imagined, genes remain the fundamental elements of heredity, evolution and development.

In depicting the course of classical genetics, Carlson devotes chapters to the history

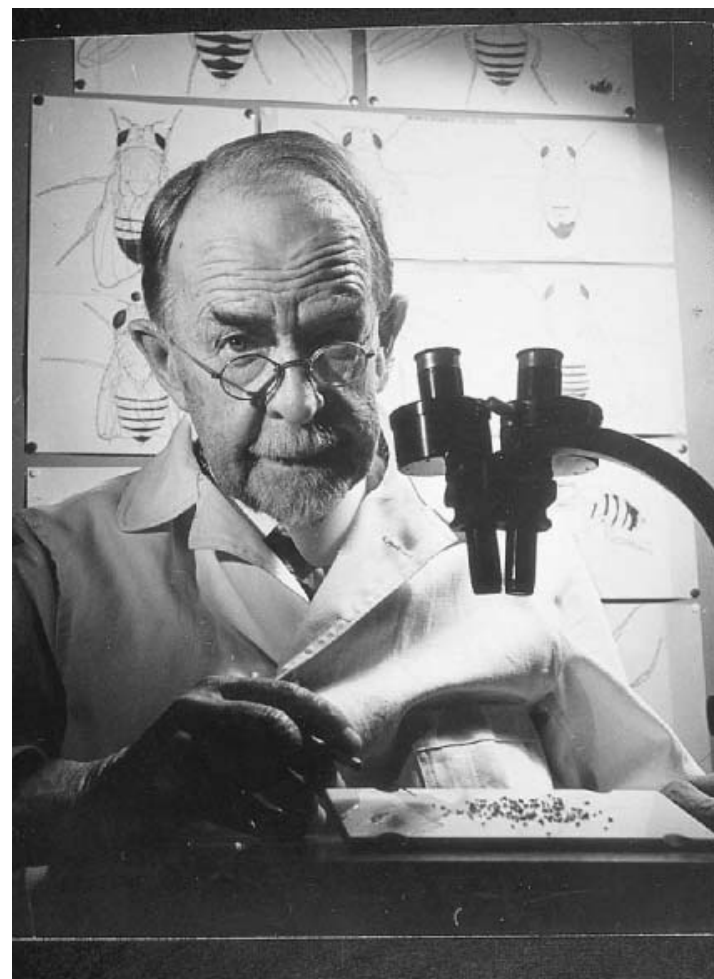

Model work: T. H. Morgan studied the genetics of fruitflies.

aspects of Kohler's study of social dynamics in the Morgan group. There is also a chapter on the fusion of mendelian genetics and darwinian evolution (the evolutionary synthesis), and glimpses into the problematic relationship between classical genetics and development in a discussion of E. B. Lewis's work on the homeotic gene complex (bithorax) in Drosophila.

Several outstanding features of this book will make it useful for specialists and non-specialists alike. One is the attempt to show how classical genetics was involved with political issues in the twentieth century, using three examples: eugenics (1883-1945), the Lysenko controversy in the Soviet Union (1930-1960), and the controversy over the genetic effects of radiation (1946-1970). Another noteworthy feature is the use of chronological tables for the whole field (at the beginning of the book), as well as for specific sub-topics, such as contributions

of evolution, cytology, embryonic development and agricultural breeding (principally the hybridization tradition in which Mendel worked). He asks a crucial historical question: if the roots of classical genetics lay in scientific traditions that were all developed in Europe, why did the United States become the place where mendelian genetics developed most rapidly and, in some ways, most successfully? Part of the answer clearly lies in the strong agrarian base in the United States at that time, with growing governmental support of agricultural research stations and the application of science to practical results.

Another part of the explanation, Carlson argues, is that the structure of the US university system was less encumbered with rigid, top-down professorial hierarchies than those in Europe. Once classical genetics had taken off, with T. H. Morgan and his group's work with the fruitfly, Drosophila melanogaster, and R. A. Emerson's group working on maize, the theory flourished by combining the cytological study of chromosome mechanics with breeding and hybridization experiments.

Carlson devotes a fair amount of space to cytology and cytogenetics, but includes the major players from all aspects of the work, including Hugo De Vries, Wilhelm Johannsen, Herman Nilsson-Ehle, W. E. Castle, E. B. Wilson, Barbara McClintock, J. B. S. Haldane and many others. Mendel's Legacy contains good thumbnail descriptions of the critical observations and experiments that went into the formation of the classical theory (more so, for example, than Robert Kohler's Lords of the Fly) while still incorporating to the chromosome theory of sex determination, or geneticists' educational background. A third valuable feature is the author's liberal use of high-quality illustrations, including photographs of many geneticists seldom pictured before, original figures from published papers, and the title pages of important papers and books. The publishers, Cold Spring Harbor Press, have produced an attractive and useful book.

By its nature, Mendel's Legacy has to be selective, so issues of the philosophical basis of the gene, on which much has been written in recent years, are omitted. This is a pity, particularly because the issues that underlie many of the disputes that Carlson describes reflected strong philosophical biases that separated the more holistic approach found among European (especially German) geneticists, such as Richard Goldschmidt (who for a major figure gets scant treatment), from the reductionist approach of the American school. National distinctions such as those described so well by Jonathan Harwood in Styles of Scientific Thought (1993) do not form a significant part of Carlson's story. Historians of science will also look askance at the sharp distinction that Carlson draws between science that he claims lacks political content (such as the function of the accessory chromosome) from that which is overtly political (notably eugenics).

All in all, however, these are minor deficiencies in a book that will certainly have broad appeal, especially within the biological community.

Garland E. Allen is professor of biology at

Washington University, St Louis, Missouri, USA. 